\title{
Focal Adhesion Proteins, Vinculin and Integrin $\beta 5$, During Early Pregnancy in Rat Uterine Epithelial Cells: Anastrozole Favors their Normal Distribution
}

\author{
Proteínas de Adhesión Focales, Vinculina e Integrina $\beta 5$, Durante el Embarazo Temprano \\ en Células Epiteliales Uterinas de Rata: Anastrozol Favorece Su Distribución Normal
}

Anthony Mwakikunga'; Gbenga A. Adefolaju ${ }^{2}$; Lynne Schepartz ${ }^{1}$ \& Margot J. Hosie $^{1,3}$

MWAKIKUNGA, A.; ADEFOLAJU, G. A.; SCHEPARTZ, L. \& HOSIE, M. J. Focal adhesion proteins, vinculin and integrin $\beta 5$, during early pregnancy in rat uterine epithelial cells: Anastrozole favors their normal distribution. Int. J. Morphol., 36(1):345-357, 2018.

SUMMARY: An alternative superovulator to replace clomiphene citrate is needed as clomiphene citrate is associated with low pregnancy rates. Anastrozole is an effective superovulator, but it has not been well researched. In order to determine the effectiveness of anastrozole as a superovulator and to compare it with clomiphene citrate in similar situations, this study ascertained the effects of these drugs on the expression of the focal adhesion proteins, vinculin and integrin $\beta 5$, which are uterine receptivity markers, in the uterine epithelial cells of day 1 and day 6 pregnant Wistar rats. The results show that vinculin and integrin $\beta 5$ are co-localized at the base of the uterine epithelium at day 1 of pregnancy whereas at day 6 , they disassemble from the basal focal adhesions and co-localize and significantly increase their expression apically $(\mathrm{p} \leq 0.0001)$. Moreover, there is a significant difference in the protein expression levels of vinculin and integrin $\beta 5$ in uterine luminal epithelial cells between untreated (control) and chlomiphene citrate treated rats $(p \leq 0.0001)$, anastrozole and chlomiphene citrate treated rats at day $6(\mathrm{p} \leq 0.0001)$ suggesting the interpretation that anastrozole seems to enhance their expression in order to perhaps assist in the implantation process of the blastocyst. The immunofluorescence experiments agree with the vinculin and integrin $\beta 5$ gene expression findings in which at day 6 of pregnancy, vinculin and integrin $\beta 5$ gene expression are significantly upregulated in uterine luminal epithelial cells in the anastrozole treated group relative to the calibrator sample $(\mathrm{p} \leq 0.0001)$. These findings suggest that anastrozole is implantation friendly.

KEY WORDS: Implantation; Uterus; Early pregnancy; Vinculin; Integrin $\beta 5$; Focal adhesion proteins.

\section{INTRODUCTION}

Cytoskeletal reorganization is an ongoing process when cells adhere, move or invade extracellular substrates. In order for cells to adhere, they employ focal adhesions (Fabry et al., 2011). Focal adhesion (FA) is a specialized structure formed where bundles of actin filaments are anchored to transmembrane receptors of the integrin family through a complex of adaptor and signaling proteins enabling cells to adhere, spread and migrate (Gilmore \& Burridge, 1996). The binding of ligands to integrins on the extracellular side promotes recruitment of various intracellular proteins to the cytoplasmic tails of integrins that mechanically link them to the actin cytoskeleton (Hirata et al., 2014). These signaling events culminate in reorganization of the actin cytoskeleton; a prerequisite for changes in cell shape and motility, gene expression and pregnancy (Lele et al., 2008; Fabry et al.; Kaneko et al., 2011). Moreover, the implantation of blastocysts into the endometrial stroma cells is regulated by the Rho GTPases RhoA, Rac 1 and Cdc42 (Grewal et al., 2010).

Other studies have provided evidence to suggest that the binding of vinculin to actin and talin can be regulated by phosphatidyl-inositol-4-5-bisphosphate (Gilmore \& Burridge) and inhibited by acidic phospholipids. Clearly,

\footnotetext{
${ }^{1}$ School of Anatomical Sciences, University of the Witwatersrand Medical School, 7, York road, Parktown 2193, Johannesburg, South Africa.

${ }^{2}$ Department of Pre-Clinical Sciences, Faculty of Health Sciences, University of Limpopo, Sovenga 0727, South Africa.

${ }^{3}$ Newcastle University Medicine Malaysia Campus, Nusajaya, Johor, Malaysia.

Funding: This work was funded by grants from the National Research Foundation and Medical Research Council of South Africa, the government of Norway (NORAD project) and College of Medicine, University of Malawi, Blantyre, Malawi.
} 
the structural links between actin filaments and integrins are regulated in at least some cell types, and it would not be unreasonable to hypothesize that agents known to alter cell behavior may do so by affecting the expression or function of actin binding proteins such as vinculin, talin, paxillin and integrins that are recruited to focal adhesions (Mwakikunga et al., 2011). Focal adhesions are dynamically assembled and disassembled by cells, including uterine luminal epithelial cells (Hosie et al., 2008; Kaneko et al., 2008, 2011), and these mechanisms are likely governed by the modulation of cross-talk between their constituent proteins, which influences their gene expression and morphology.

Gonadotropin injections are medically dangerous and invasive, and their compliance is not easy. They are also associated with multiple pregnancies (Bruna-Catalán et al., 2011). Similarly, polycystic ovarian syndrome patients are resistant to chlomiphine citrate (Casper \& Mitwally, 2011). Aromatase inhibitors (AIs) such as letrozole and anastrozole, which are used to treat breast cancer, have been suggested as alternatives to gonadotropins and chlomiphine citrate due to their easy compliance and oral administration (Lee \& Ledger, 2011). The use of letrozole as a first line therapy for women with anovulation is not fully conclusive and still remains deba(Kamath \& George, 2011). Anastrozole is clinically effective in ovulation induction, but it has not been well researched (Tredway \& Schertz, 2011). Investigating and understanding the effects of anastrozole on the endometrium at the time of implantation in vivo will enable manipulation of uterine receptivity to control fertility and to improve the outcome of assisted reproductive procedures (Paria et al., 2001; Hosie et al., 2003; Karaer et al., 2005).

Since blastocyst adhesion onto the endometrium is at the center of the implantation process (Enders et al., 1986; Murphy, 2004), this means that focal adhesion proteins are employed. The expression and distribution of the focal adhesion proteins in the rat uterine epithelial cells are associated with uterine receptivity (Kaneko et al., 2008). In other words, the dynamics of focal adhesions are crucial at the time of implantation. Disassembly of the basal focal adhesions along the uterine epithelial cells makes cells less adherent to the underlying basement membrane, and this facilitates their removal, enabling embryonic trophoblast cells to invade the endometrial decidual cells beneath. Since previous studies demonstrated that focal adhesion proteins are more likely regulated in uterine epithelia to change cell behavior (Kaneko et al., 2009), and that super-ovulatory drugs can alter expression of key molecules in the uterine epithelial cells during implantation (Hosie et al., 2003), anastrozole may act on focal adhesion proteins during implantation. To date, anastrozole regulation of focal adhesion proteins in the uterine epithelial cells during implantation has not been established.
The aim of this study was to determine the gene and protein expression levels and localization of the focal adhesion proteins vinculin and integrin $\beta 5$ in the rat uterine epithelial cells during implantation in vivo.

\section{MATERIAL AND METHOD}

Animals. The study was approved by the University of the Witwatersrand Animal Ethics Committee with a clearance certificate number: 2012/11/03.

Thirty five female virgin inbred Wistar rats were used in the preliminary dose response study (Mwakikunga \& Hosie, 2016) to determine the optimal dose of anastrozole required to superovulate rats in the main study. On day 6 pregnant rats were used in the preliminary study (Mwakikunga \& Hosie). A chlomiphene citrate (CC) treatment group was also used as a control to compare with the anastrozole treatment groups. Rats were housed in plastic cages at $21^{\circ} \mathrm{C}$ under a controlled 12 hour light-dark cycle. They were provided with water and food ad libitum (Dukes et al., 1996). Vaginal smears were obtained from all female rats to confirm that they had regular cycles for two cycles before drug administration (Singletary et al., 2005; Jaramillo et al., 2012). Thirty five mature female rats, 12 to 14 weeks old and weighing 200-250 g, were randomly divided into 7 groups of 5 rats each. Vaginal smear was done in the late afternoon (Kaneko et al., 2008) and rats in pro-oestrus were treated with the drugs or placebo and then caged overnight with males of proven fertility. The morning of finding the vaginal plug or presence of spermatozoa in the smear was designated as day 1 of pregnancy (Kaneko et al., 2008).

Rationale for the doses. A daily dose of $1 \mathrm{mg} / \mathrm{kg}$ anastrozole (Sigma-Aldrich Co., St. Louis, MO, USA) for 5 days is the standard recommended dose to achieve ovulation in humans (Franik et al., 2014). A 12-14 week mature female Wistar rat weighs between 200-250 $\mathrm{g}$ and has a 4-day estrous cycle, so a single dose of anastrozole administered at pro-estrus was deemed appropriate. Kilic-Okman et al. (2003) employed a similar regime using letrozole. Earlier studies have suggested that the standard $1 \mathrm{mg} / \mathrm{kg}$ anastrozole of body weight dose is too low for optimal follicle recruitment and ovulation, so higher doses are recommended (Al-Omari et al., 2004; Casper \& Mitwally, 2012). A single $25 \mathrm{mg} / \mathrm{kg}$ anastrozole dose has been successful in inducing ovulation in mice and is associated with favorable embryo development (Karaer et al.). However, in our preliminary work, a drug concentration study with anastrozole was carried out to determine the optimal dose to be used to superovulate and achieve pregnancy in the Wistar rats (Mwakikunga \& Hosie). This was found to be dose- 
Table I. Anastrozole and CC dose regimes made up to $0.2 \mathrm{ml}$ normal saline for the 7 groups of mature female Wistar rats undergoing ovulation stimulation.

\begin{tabular}{llc}
\hline Groups & Treatments & $\begin{array}{c}\text { Number } \\
\text { of rats }\end{array}$ \\
\hline 1 & Untreated* $^{*}$ & 5 \\
2 & Saline (vehicle)* & 5 \\
3 & $1 \mathrm{mg} / \mathrm{kg}$ anastrozole & 5 \\
4 & $10 \mathrm{mg} / \mathrm{kg}$ anastrozole & 5 \\
5 & $15 \mathrm{mg} / \mathrm{kg}$ anastrozole* & 5 \\
6 & $25 \mathrm{mg} / \mathrm{kg}$ anastrozole & 5 \\
7 & $1.25 \mathrm{mg} / \mathrm{kg}$ chlomiphene citrate* & 5 \\
\hline
\end{tabular}

specific, and the $15 \mathrm{mg} / \mathrm{kg}$ anastrozole dose superovulated and achieved pregnancy the most; therefore, this dose was used in the subsequent experiments in this study. Dose rates in the preliminary work were started at $1 \mathrm{mg} / \mathrm{kg}$. The chlomiphene citrate dose of $1.25 \mathrm{mg} / \mathrm{kg}$ (Sigma-Aldrich Co., St. Louis, MO, USA) was adopted from earlier studies (Hosie et al., 2003) and used as a comparison.

\section{Drug preparation and administration}

Treatment regimes for the dose response study. Anastrozole has moderate aqueous solubility and previous studies used normal saline as a vehicle for anastrozole (Karaer et al.; Fatum et al., 2006). In this study, the vehicle for all of the drugs was normal saline and each injection consisted of $0.2 \mathrm{ml}$ normal saline (Fatum et al.) including the drug per injection per rat. All injections were intraperitoneal. The four anastrozole dose regimes for the preliminary dose response study were: $25 \mathrm{mg}, 15 \mathrm{mg}, 10$ $\mathrm{mg}$, and $1 \mathrm{mg} / \mathrm{kg}$ body weight.

Treatment regimes: Group 1 was left untreated (negative control). Group 2 (carrier control group) received the vehicle sterile saline. Groups 3, 4, 5 and 6 received a single dose of $1 \mathrm{mg} / \mathrm{kg}$, $10 \mathrm{mg} / \mathrm{kg}, 15 \mathrm{mg} / \mathrm{kg}$ and $25 \mathrm{mg} / \mathrm{kg}$ of body weight anastrozole respectively in the pro-estrous phase intraperitoneally. Group 7 received $1.25 \mathrm{mg} / \mathrm{kg}$ of body weight $\mathrm{CC} ; \mathrm{n}=5$ in each group, all $0.2 \mathrm{ml}$ intraperitoneal injections (I).
Tissue preparation. Pregnant rats were sacrificed on day 6 at the time of implantation using a lethal dose $(0.35 \mathrm{ml})$ of Euthanase, intraperitoneally $(1 \mathrm{ml} / \mathrm{kg}$ is recommended; Kyron Labs, South Africa). Once deeply unconscious, the abdominal cavity was opened and the rats to be sacrificed on day 6 of pregnancy were injected intravenously using the inferior vena cava with $0.1 \mathrm{ml}$ of $1 \%$ high molecular weight vital dye Pontamine sky blue (Sigma, St. Louis, MO, USA) in normal saline $(0.9 \% \mathrm{NaCl})$ (Pakrasi \& Tiwari, 2007), in order to distinguish implantation sites from nonimplantation sites. This dye quickly localizes in the implantation sites due to increased vascularization and vascular permeability during early pregnancy (Psychoyos, 1986). After removal of the uterine horns, implantation sites were counted and recorded. The uterus was cut into $1 \mathrm{~cm}$ pieces separating implantation and non-implantation sites and prepared for scanning electron microscopy (SEM), confocal microscopy and qPCR.

Animals for the main study (confocal microscopy and qPCR). A further twenty similar female rats to be sacrificed on day 1 of pregnancy were used in themain study. Five rats were treated with $15 \mathrm{mg} / \mathrm{kg}$ anastrozole (as this was found to be the optimal dose) (Mwakikunga \& Hosie), five were treated with $1.25 \mathrm{mg} / \mathrm{kg} \mathrm{CC}$, five were treated with saline alone, and five were untreated. These matched the groups in the earlier study where the animals were sacrificed on day 6 of pregnancy.

\section{Immunofluorescence and confocal microscopy}

Tissue processing and sectioning. All histological glass slides that were used in this study were gelatin-coated (Rajamohamedsait \& Sigurdsson, 2012) in order to stick the tissue sections to the slides during the staining and washing process. Using standard procedures, samples for immunofluorescence and confocal microscopy were fixed in $10 \%$ buffered formalin for 48 hours (Karaer et al.), then placed in an automatic tissue processor (Shandon Citadel 1000, Labotek, South Africa) in which samples were incubated in a series of $70 \%, 95 \%, 95 \%, 95 \%, 100 \%, 100$ $\%, 100 \%$ ethanol, then in chloroform and finally in paraffin

Table II. Description of the scoring system for the focal adhesion protein expression and localization in the confocal images among treatment groups adopted from previous studies (Englund et al., 2001; Mwakikunga et al., 2011).

\begin{tabular}{ll}
\hline Epith elial immunohistochemical characteristics & Scoring system \\
\hline Protein expression & Whether the epithelium is positively stained or not: \\
& ( 0 , negative staining, intensity absent) \\
& (1, positive staining and 1 to $10 \%$ positively stained epithelium, low intensity) \\
& (2, positive staining and 11 to $50 \%$ positively stained epithelium, medium intensity) \\
& (3, positive staining and 51 to $100 \%$ positively stained epithelium, high intensity)Protein \\
& localization in the epithelium) \\
& $(1$, basal; 2 , apical; 3,lateral; 4 , basolateral; 5 , basal and apical) \\
Main epithelial domain protein localization & (1, cytoplasmic; 2 , perinuclear; 3, evenly distributed in epithelial cell; 4, stroma). \\
Additional protein localization &
\end{tabular}


wax. Samples were then embedded in paraffin wax. Histological sections $(5 \mu \mathrm{m})$ were cut using a Leica 2035 Biocut microtome (Leica, Nussloch, Germany) fitted with a disposable blade and then dewaxed overnight by placing them in an oven at $60{ }^{\circ} \mathrm{C}$, then immersed in histoclear for 5 minutes and then repeated in fresh histoclear for 5 minutes, rehydrated through a graded series of ethanol $(100 \%, 100$ $\%, 95 \%, 80 \%, 70 \%$ and $60 \%$ ) for 30 seconds each, then washed in running water for 5 minutes (Mohan et al., 2008; Rajamohamedsait \& Sigurdsson, 2012).

Immunofluorescence. The immunolocalization and double labeling protocol was adopted and modified from previous studies (Mohan et al.; Kaneko et al., 2011; Mwakikunga, et $a l$. .). De-waxed sections of uterus from each group were washed 3 times, 2 min each with PBS. This was followed by a $10 \mathrm{~min}$ incubation in $30 \% \mathrm{H}_{2} \mathrm{O}_{2}$ (Sigma-Aldrich Co., St. Louis, MO, USA) in methanol to block endogenous peroxidase activity (Mwakikunga et al.), and then washed 3 times, 2 min each with PBS. Sections were then permeabilized for 30 minutes in $0.1 \%$ Triton-X 100 (Sigma-Aldrich Co., St. Louis, MO, USA) in PBS, and incubated for 30 minutes in blocking solution $5 \%(\mathrm{v} / \mathrm{v})$ normal goat serum (Sigma-Aldrich Co., St. Louis, MO, USA) in PBS. All primary and secondary antibodies were diluted in blocking solution (1:100). Sections were incubated with mouse monoclonal anti-Vinculin, rabbit polyclonal anti-Integrin (Abcam, Cambridge, MA, USA) for 24 hours at $4^{\circ} \mathrm{C}$ (double staining: vinculin with integrin $\beta 5$ ) (Mohan et al.; Kaneko et al., 2011). After washing with PBS
3 times 5 min each, sections were incubated with fluorescein isothiocyanate (FITC) conjugated to AffiniPure Goat antimouse $\operatorname{IgG}$ secondary antibody (Abcam) and rodamine conjugated Goat anti-rabbit IgG secondary (Abcam) at a dilution of 1:100 [10] for $30 \mathrm{~min}$ in the dark followed by 3 PBS washes of 5 min each. Sections were also counterstained with DAPI to label nuclei. Expression and localization of vinculin and integrin $\beta 5$ were examined under the Zeiss LSM 780 confocal microscope (Carl Zeiss, Jena, Germany) and images were acquired using the Zeiss LSM software (Carl Zeiss, Jena, Germany). The focal adhesion protein expression levels and localization in the confocal images were scored using a scoring method modified from previous studies (Englund et al., 2001) as shown in Table II. JMP10 software (SAS Institute, Cary, NC, USA) was used for the statistical comparisons of means of focal adhesion protein expression of vinculin and integrin $\beta 5$ among treatment groups using a one way ANOVA followed by a TukeyKramer post hoc analysis. Differences were considered statistically significant when $\mathrm{p} \leq 0.05$.

Real time quantitative polymerase chain reaction (qPCR). In this study, the qPCR was performed for the quantitation of gene expression of the focal adhesion proteins vinculin and integrin $\beta 5$ in the uterine epithelial cells from day 1 and day 6 pregnant rats of all treatment regimes. The house keeping genes b-actin, 18Sr RNA and Lactate dehydrogenase A (Ldha) were used as reference genes (AlBader \& Al-Sarraf, 2005; Hong et al., 2006; Li et al., 2014).

Table III. Description of the real time PCR primer sequence characteristics for the genes of interest and reference genes used in the study.

\begin{tabular}{|c|c|c|c|c|c|c|}
\hline $\begin{array}{l}\text { Gene } \\
\text { symbol }\end{array}$ & Gene name & $\begin{array}{l}\text { RefSeq GenBank } \\
\text { Accession Number }\end{array}$ & $5^{\prime}-3^{\prime}$ primer sequence & $\begin{array}{c}\text { Position of } \\
\text { primer on } \\
\text { template }\end{array}$ & $\begin{array}{c}\mathrm{GC} \\
\text { content }\end{array}$ & $\begin{array}{l}\text { Amplicon } \\
\text { length (bp) }\end{array}$ \\
\hline \multirow[t]{2}{*}{$\mathrm{Vcl}$} & \multirow[t]{2}{*}{ Vinculin } & \multirow[t]{2}{*}{ NM 001107248.1} & $\begin{array}{l}\text { F: 5'- GTT CCC GGT TTT CTG TTG CC - } \\
\text { 3' (20 bases) }\end{array}$ & $40--59$ & $55 \%$ & \multirow[t]{2}{*}{139} \\
\hline & & & $\begin{array}{l}\text { R: 5'- GCC CTC GTG CAT AAT CA -3' } \\
(20 \text { bases })\end{array}$ & $178--159$ & $55 \%$ & \\
\hline \multirow[t]{2}{*}{ Itgb5 } & \multirow[t]{2}{*}{ Integrin, beta 5} & \multirow[t]{2}{*}{ NM 147139.2} & $\begin{array}{l}\text { F: 5'- GTG CGA CAG CTT TTC CTG TG } \\
-3^{\prime} \text { (20 bases) }\end{array}$ & $1694--1713$ & $55 \%$ & \multirow[t]{2}{*}{97} \\
\hline & & & $\begin{array}{l}\text { R: 5'- AAT GTA ACC GAC GTG GCA CT } \\
-3^{\prime} \text { (20bases) }\end{array}$ & $1790--1771$ & $50 \%$ & \\
\hline \multirow[t]{2}{*}{ Actb } & \multirow[t]{2}{*}{ Actin, beta } & \multirow[t]{2}{*}{ NM 031144.3} & $\begin{array}{l}\text { F: 5' - GCA GGA GTA CGA TGA GTC } \\
\text { CG -3' (20 bases) }\end{array}$ & $1155--1174$ & $60 \%$ & \multirow[t]{2}{*}{74} \\
\hline & & & $\begin{array}{l}\text { R: 5' }- \text { ACG CAG CTC AGT AAC AGT } \\
\text { CC -3' (20 bases) }\end{array}$ & 1228--1209 & $55 \%$ & \\
\hline \multirow[t]{2}{*}{ Ldha } & \multirow{2}{*}{$\begin{array}{l}\text { Lactate } \\
\text { dehydro-genase } \\
\text { A }\end{array}$} & \multirow[t]{2}{*}{ NM 017025.1} & $\begin{array}{l}\text { F: 5' - CCG TTA CCT GAT GGG AGA } \\
\text { AA -3' (20 bases) }\end{array}$ & $613--632$ & $50 \%$ & \multirow[t]{2}{*}{108} \\
\hline & & & $\begin{array}{l}\text { R: 5' - ACG TTC ACA CCA CTC CAC } \\
\text { AC -3' (20 bases })\end{array}$ & $720--701$ & $55 \%$ & \\
\hline \multirow[t]{2}{*}{$18 \mathrm{~s}$} & \multirow[t]{2}{*}{ 18Sr RNA } & \multirow[t]{2}{*}{ X01117.1 } & $\begin{array}{l}\text { F: 5' - GTT GGT TTT CGG AAC TGA } \\
\text { GGC -3' (21 bases) }\end{array}$ & $895--915$ & $52.4 \%$ & \multirow[t]{2}{*}{204} \\
\hline & & & $\begin{array}{l}\text { R: 5' - GTC GGC ATC GTT TAT GGT } \\
\text { CG -3' (20 bases) }\end{array}$ & 1098--1079 & $55 \%$ & \\
\hline
\end{tabular}


The RNA from the uterine epithelial cells was prepared with the GeneJET RNA purification kit (Thermo Scientific Inc., 2011), and genomic DNA was removed according to the manufacturer's instructions (Thermo Scientific Inc., 2011). For qPCR, amplification was performed in a 7500 real-time PCR cycler (Applied Biosystems, Foster City, CA) and revealed with a QuantiFast SYBR Green PCR kit (Thermo Fisher Scientific Inc., 2011). The amplification cycling conditions were as follows: $95^{\circ} \mathrm{C}$ for $10 \mathrm{~min},\left(95^{\circ} \mathrm{C}\right.$ for 15 $\mathrm{s}, 60{ }^{\circ} \mathrm{C}$ for $1 \mathrm{~min}$ in 40 cycles), $95^{\circ} \mathrm{C}$ for $15 \mathrm{~s}, 60^{\circ} \mathrm{C}$ for $1 \mathrm{~min}, 95^{\circ} \mathrm{C}$ for $30 \mathrm{~s}, 60^{\circ} \mathrm{C}$ for $15 \mathrm{~s}$. Table III shows the primer sequences for the real-time qPCR.

SYBR green qPCR data analysis. The $2^{-\Delta \Delta C T}$ method was used to determine the gene expression fold change relative to the control (calibrator sample) following drug treatment regime (Schmittgen \& Livak, 2008). The data (threshold cycle or ct values) were first normalized using the three reference genes ( $\beta$-actin, 18S rRNA and lactate dehydrogenase A); then the fold change was calculated (Schmittgen \& Livak, 2008). JMP10 software was used to conduct statistical analyses. A one way ANOVA, followed by a Tukey-Kramer post hoc analysis, was performed to compare the means of normalized relative quantities (NRQ) between treatment groups. Differences were considered statistically significant when $\mathrm{p}$ $\leq 0.05$.

\section{RESULTS}

Vinculin and integrin $\beta 5$ localization. Vinculin and integrin $\beta 5$ are co-localized at the base of the uterine epithelium at day 1 of pregnancy whereas at day 6 , they disassemble from the basal focal adhesions and colocalize and significantly increase their expression apically ( $\mathrm{p} \leq 0.0001)$ as noted in Figs. 1, 2, 3, 4 and Table IV. Additionally, vinculin is expressed in the perinuclear region at day 1 and relocates apically at day 6 of pregnancy as seen in Figs. 1, 2, 3, 4. Moreover, there is a significant difference ( $\mathrm{p} \leq 0.0001$ ) in the expression levels of both vinculin and integrin b5 between untreated (control) and chlomiphene citrate $(\mathrm{CC})$ treated rats, anastrozole and CC treated rats at both day 1 and day 6 as seen in Figs. 1, 2, 3 , 4. Although there is no significant difference in the expression levels between untreated and anastrozole treated rats at day 1 and day $6(\mathrm{p} \leq 0.05)$, the means for vinculin and integrin $\beta 5$ expression are higher in the anastrozole treated groups. The non-immune controls (not shown) were used to validate and determine non-specific binding of the secondary antibody on other targets within the epithelium; there is no non-specific staining.

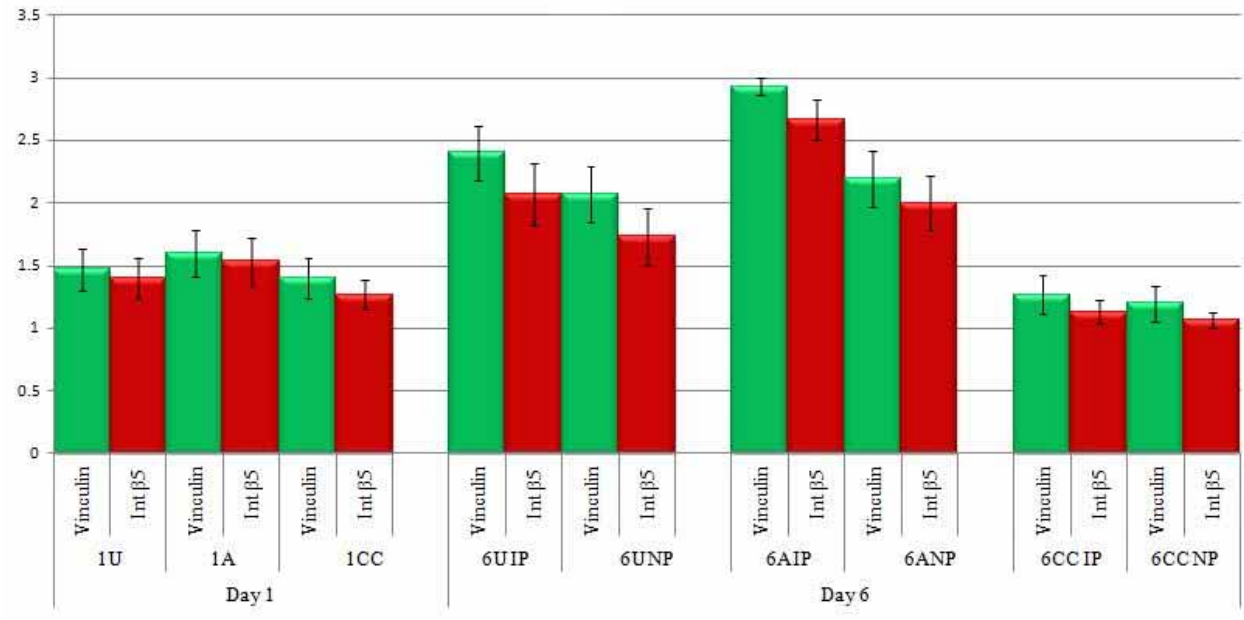

Fig. 1. Vinculin and intergrin $\beta 5$ expression in the surface luminal uterine epithelial cells of day 1 and day 6 pregnant rats. There is a significant difference in the expression of vinculin and integrin $\beta 5$ between anastrozole day 1 and day $6(\mathrm{p} \leq 0.0001)$, untreated (control) day 1 and day $6(\mathrm{p} \leq 0.0001)$, untreated day 6 and $\mathrm{CC}$ day $6(\mathrm{p} \leq 0.0001)$. No significant difference in vinculin and integrin b5 expression is noted between chlomiphene citrate day 1 and chlomiphene citrate day $6(\mathrm{p} \leq 0.05)$, untreated day 6 and anastrozole day $6(\mathrm{p} \leq 0.05)$. Generally, chlomiphene citrate (CC) seems to decrease their expression while anastrozole seems to enhance their expression as pregnancy progresses. Note: numerical scale on the left represents the scoring system average scores as described previously in Table II. 


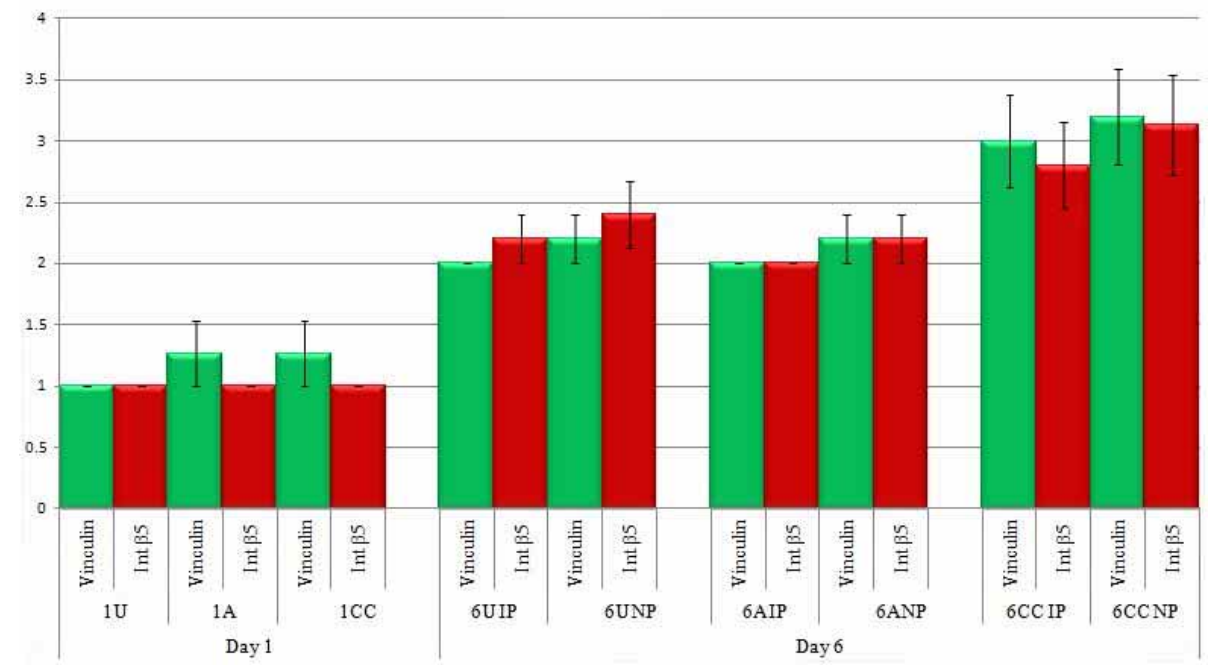

Fig. 2. Vinculin and intergrin $\beta 5$ uterine epithelial localization. Vinculin and integrin $\beta 5$ are colocalized at the base of the uterine epithelium at day 1 of pregnancy whereas at day 6 , they disassemble from the basal focal adhesions and co-localize and significantly increase their expression apically ( $\mathrm{p} \leq 0.0001)$ as also noted in Figs. 3 and 4. Note: vinculin is also expressed in the perinuclear region at day 1 and relocates apically at day 6 of pregnancy in the untreated and anastrozole treated rats as seen in Figs. 3 and 4. Note: numerical scale on the left represents the scoring system average scores as described previously in Table II (1, basal; 2, apical; 3, lateral; 4, basolateral; 5, basal and apical).

Relative quantification (RQ) analysis of vinculin and integrin $\beta 5$ gene expression in the uterine epithelial cells from day 1 and day 6 pregnant rats. At day 1 of pregnancy, vinculin gene expression in uterine luminal epithelial cells is fairly similar (1.2-fold increase) in the anastrozole treated rats relative to the calibrator sample (day 1 untreated rats). This is also true for integrin $\beta 5$ gene expression (1.01-fold increase) $(\mathrm{p}<0.05)$. Vinculin and integrin $\beta 5$ gene expression in uterine luminal epithelial cells, however, is down-regulated (0.77-fold decrease) and (0.79fold decrease) respectively with chlomiphene citrate (CC) treatment at day 1 of pregnancy relative to the calibrator sample as shown in Tables V and VI and Figure 5. Interestingly, like the immunofluorescence experiments, at day 6 of pregnancy vinculin and integrin $\beta 5$ gene expression are significantly up-regulated (more than 1.5 -fold increase) $(\mathrm{p} \leq 0.0001)$ in uterine luminal epithelial cells in the implantation and non-implantation sites in the anastrozole treated group relative to the calibrator sample (Tables $\mathrm{V}$ and VI and Fig. 5). A significant increase in the integrin $\beta 5$ gene expression is also noted in uterine luminal epithelial cells of day 6 implantation sites in the untreated group (more than

Table IV. A summary of vinculin and integrin $\beta 5$ expression and localization.

\begin{tabular}{|c|c|c|c|}
\hline & & Vinculin & Integrin $\beta 5$ \\
\hline \multirow[t]{2}{*}{ Day 1} & Untreated & $\begin{array}{l}\text { Medium intensity expression in focal adhesions at } \\
\text { the base of } \mathrm{t} \text { he epithelium with some sparse } \\
\text { perin uclear region expression }\end{array}$ & $\begin{array}{l}\text { Medium intensity expression in focal adhesions at } \\
\text { the base of the epithelium }\end{array}$ \\
\hline & $\mathrm{CC}$ & $\begin{array}{l}\text { Medium intensity expression in focal adhesions at } \\
\text { the base of the epithelium }\end{array}$ & $\begin{array}{l}\text { Medium intensity expression in focal adhesions at } \\
\text { the base of the epithelium }\end{array}$ \\
\hline \multirow[t]{3}{*}{ Day 6 IP } & Untreated & High intensity apical cytoplasmic expression & High intensity apical cytoplasmic expression \\
\hline & Anastrozole & High intensity apical cytoplasmic expression & High intensity apical cytoplasmic expression \\
\hline & $\mathrm{CC}$ & Low intensity apical cytopl asmic ex pression & Low int ensity apical cytoplasmic expression \\
\hline \multirow[t]{3}{*}{ Day $6 \mathrm{NP}$} & Untreated & High intensity apical cytoplasmic expression & High intensity apical cytoplasmic expression \\
\hline & Anastrozole & High intensity apical cytoplasmic expression & High intensity apical cytoplasmic expression \\
\hline & $\mathrm{CC}$ & Low intensity apical cytopl asmic ex pression & Low int ensity apical cytoplasmic expression \\
\hline
\end{tabular}




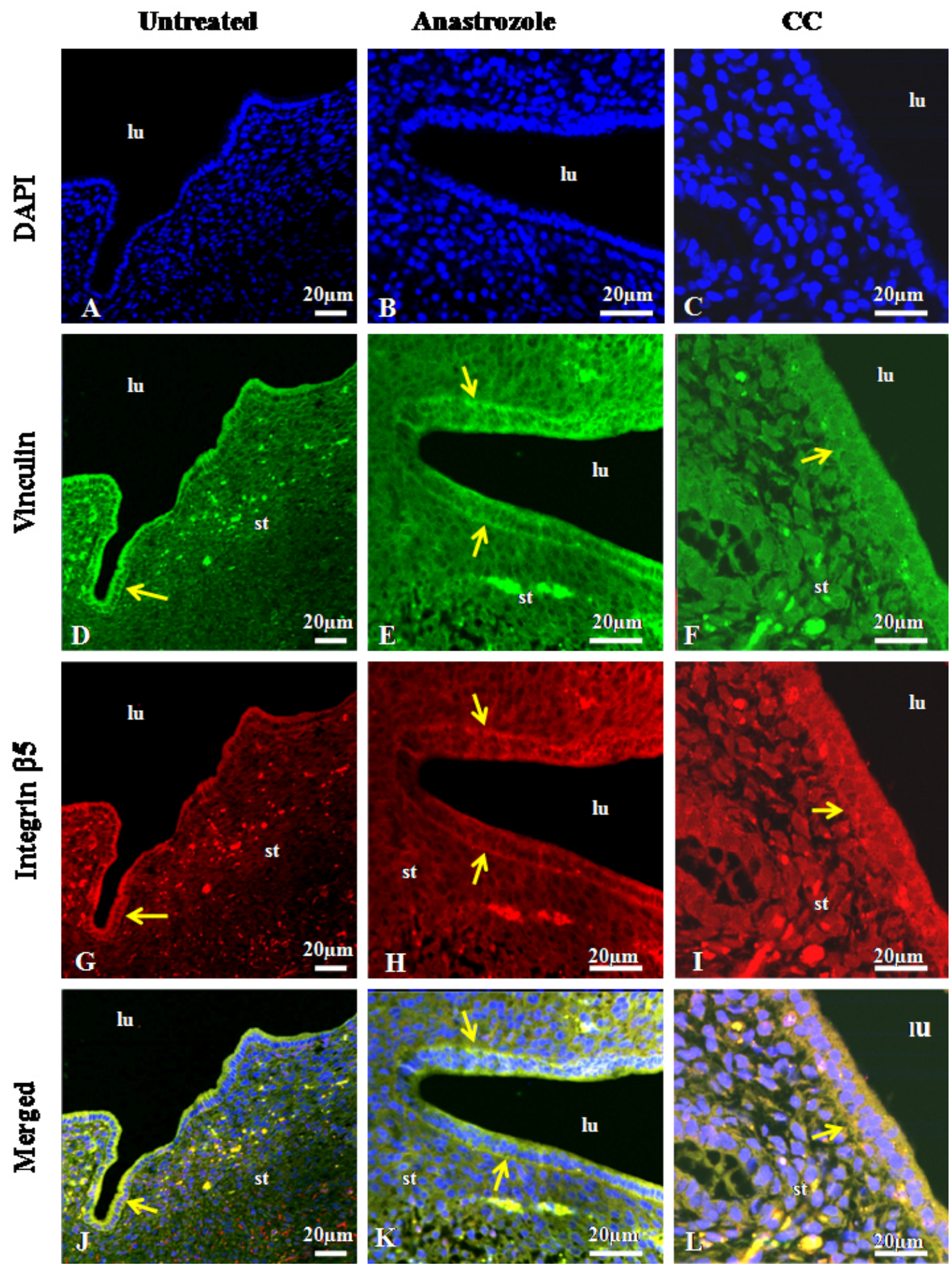

Fig. 3. Micrograph showing vinculin and integrin $\beta 5$ expression and co-localization in luminal uterine epithelial cells from day 1 of pregnancy in rats. (A), (B) and (C) show nuclei stained with DAPI (blue). (D) and (E) A distinct band of vinculin (green, FITC) expression at the base of the uterine epithelium (yellow arrow) is noted in both untreated and anastrozole treated rats. (F) The basal expression of vinculin in chlomiphene citrate (CC) treated rat is not as high as in (D) and (E). (G) and (H) A distinct band of integrin $\beta 5$ (red, rodamine) expression at the base of the uterine epithelium (yellow arrow) is noted in both untreated and anastrozole treated rats. (I) The basal expression of integrin $\beta 5$ in CC treated rat is not as high as in $(\mathrm{G})$ and $(\mathrm{H})$. (J), (K) and (L) Vinculin and integrin $\beta 5$ co-localize basally on day 1 of pregnancy. All images are representative of staining from the 5 rats in each of the treatment regimes. 


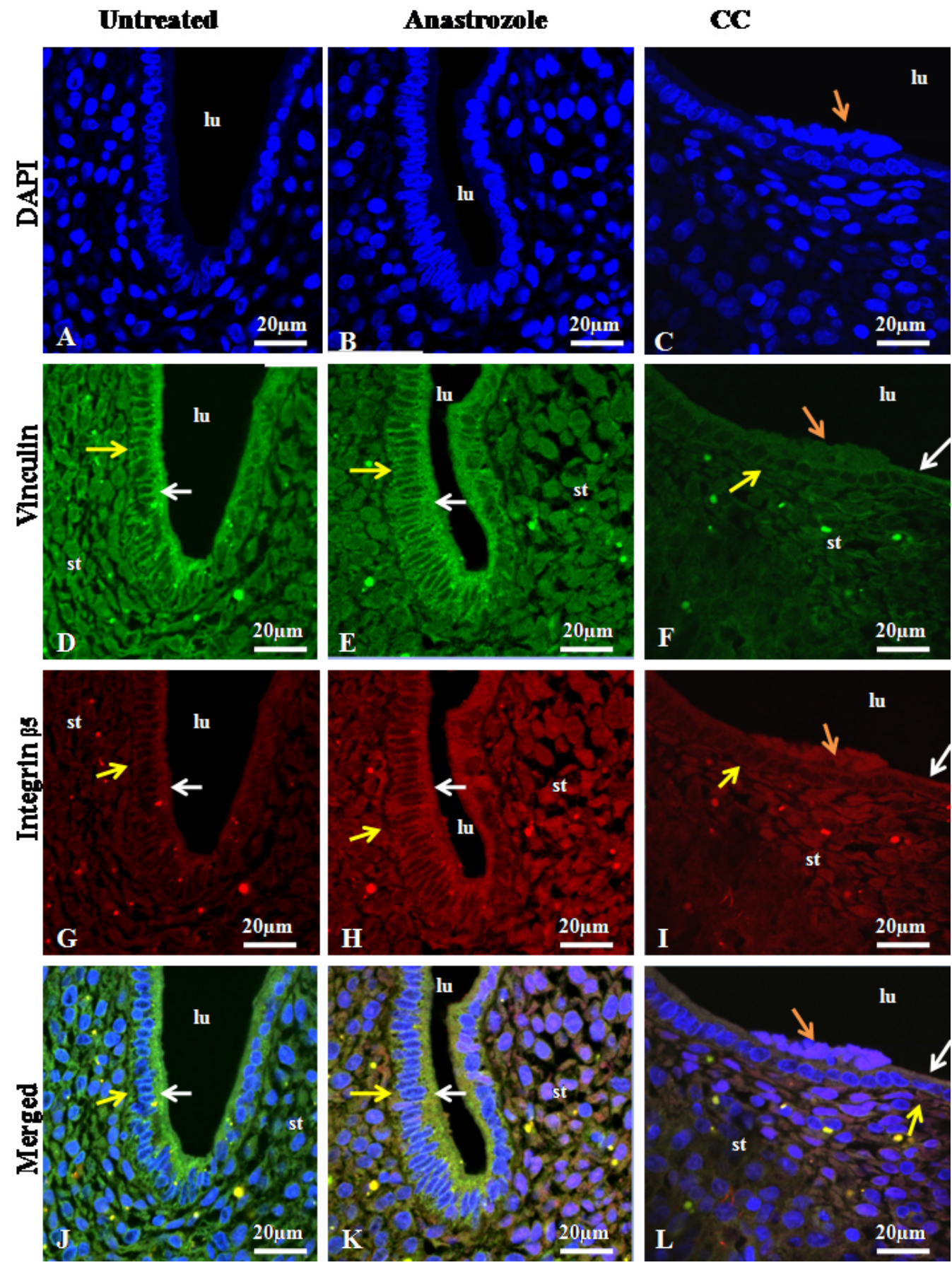

Fig. 4. Micrograph showing vinculin and integrin $\beta 5$ expression and co-localization in luminal uterine epithelial cells from implantation sites of day 6 pregnant rats. (A), (B) and (C) show nuclei stained with DAPI (blue); orange arrow shows the embryo. (D) and (E) Vinculin (green, fluorescein isothiocyanate (FITC) disassemble from the base of the epithelium (yellow arrows) and become highly expressed apically (white arrows) in both untreated and anastrozole treated rats. (F) The apical expression of vinculin in chlomiphene citrate $(\mathrm{CC})$ treated rat is down-regulated. $(\mathrm{G})$ and $(\mathrm{H})$ Integrin $\beta 5$ (red, rodamine) disassemble from the base of the epithelium (yellow arrows) and become highly expressed apically (white arrows) in both untreated and anastrozole treated rats. (I) The apical expression of integrin $\beta 5$ in $\mathrm{CC}$ treated rat is down-regulated. $(\mathrm{J}),(\mathrm{K})$ and $(\mathrm{L})$ Vinculin and integrin $\beta 5$ co-localize apically on day 6 of pregnancy. All images are representative of staining from the 5 rats in each of the treatment regimes. 
1.5 -fold increase) $(\mathrm{p} \leq 0.0001)$ while it has remained similar (1.04-fold increase) $(\mathrm{p} \leq 0.05)$ in the non-implantation sites relative to the calibrator sample (Tables V and VI and Fig. 5). However, vinculin gene expression in uterine luminal epithelial cells is down-regulated with CC treatment at day 6 in implantation sites (0.96-fold decrease) and non-implantation sites ( 0.93 -fold decrease) relative to the calibrator sample. This is also true for integrin b5 gene expression (0.86-fold decrease and 0.42 -fold decrease) respectively. In general, there is an increase in vinculin and integrin b5 gene expression at day 6 of pregnancy in uterine luminal epithelial cells in untreated and anastrozole treated groups, as reflected in the immunofluorescence experiments.

\section{DISCUSSION}

In this study, the focal adhesion proteins vinculin and integrin $\beta 5$ are co-localized at the base of the uterine

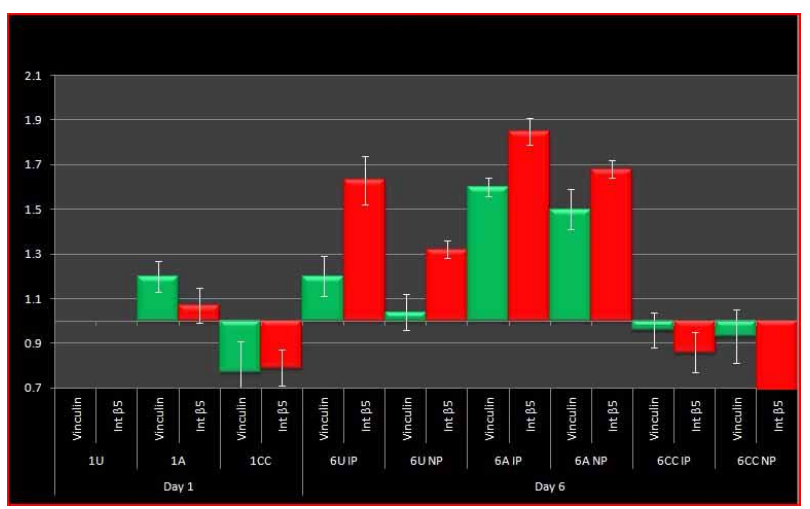

Fig. 5. Graphical representation of vinculin and intergrin $\beta 5$ gene expression in the surface luminal uterine epithelial cells of day 1 and day 6 pregnant rats. There is a significant difference in the gene expression of vinculin and integrin $\beta 5$ between anastrozole day 1 and day 6 (p $\leq 0.0001)$, untreated (control) day 1 and day 6 (p $\leq 0.0001)$, untreated day 6 and $C C$ day $6(\mathrm{p} \leq 0.0001)$. No significant difference is noted between CC day 1 and CC day $6(\mathrm{p} \leq 0.05)$, untreated day 6 and anastrozole day $6(\mathrm{p} \leq 0.05)$. Note: Generally, chlomiphene citrate (CC) seems to decrease their expression while anastrozole seems to enhance their expression as pregnancy progresses.'

Table V. Relative quantification (RQ) analysis of vinculin gene expression in the luminal surface uterine epithelial cells of day 1 and day 6 of pregnant rats. A fold change of 1.5 or more represents a significant difference in gene expression $(\mathrm{p} \leq 0.05)$.

\begin{tabular}{lllllll}
\hline Sample & Vin Ave $C_{\mathrm{T}}$ & ${ }^{*}$ RFG Ave $C_{\mathrm{T}}$ & $\Delta \mathrm{C}_{\mathrm{T}}$ & $\Delta \Delta \mathrm{C}_{\mathrm{T}}$ & $\log _{10}\left(2^{-\Delta \Delta \mathrm{CT}}\right)$ & Fold change $2^{-\Delta \Delta C \mathrm{CT}}$ \\
\hline$* * 1 \mathrm{U}$ & $24.40 \pm 0.01$ & $22.81 \pm 0.03$ & $1.59 \pm 0.03$ & $0 \pm 0.03$ & 0 & $\mathbf{1}(0.97$ to 1.02$)$ \\
1A & $24.14 \pm 0.06$ & $22.75 \pm 0.04$ & $1.39 \pm 0.07$ & $-0.2 \pm 0.07$ & 0.08 & $\mathbf{1 . 2}(1.09$ to 1.21$)$ \\
1CC & $24.81 \pm 0.13$ & $22.82 \pm 0.06$ & $1.99 \pm 0.14$ & $0.4 \pm 0.14$ & -0.11 & $\mathbf{0 . 7 7}(0.69$ to 0.84$)$ \\
6U IP & $23.96 \pm 0.03$ & $22.59 \pm 0.09$ & $1.37 \pm 0.09$ & $-0.22 \pm 0.09$ & 0.08 & $\mathbf{1 . 2}(1.09$ to 1.24$)$ \\
6U NP & $23.91 \pm 0.07$ & $22.37 \pm 0.04$ & $1.54 \pm 0.08$ & $-0.05 \pm 0.08$ & 0.02 & $\mathbf{1 . 0 4}(0.98$ to 1.09$)$ \\
6A IP & $23.17 \pm 0.03$ & $22.19 \pm 0.02$ & $0.98 \pm 0.04$ & $-0.61 \pm 0.04$ & 0.20 & $\mathbf{1 . 6}(1.5$ to 1.6$)$ \\
6A NP & $24.19 \pm 0.07$ & $23.17 \pm 0.03$ & $1.02 \pm 0.08$ & $-0.57 \pm 0.08$ & 0.18 & $\mathbf{1 . 5}(1.4$ to 1.5$)$ \\
6CC IP & $25.18 \pm 0.28$ & $23.52 \pm 0.05$ & $1.66 \pm 0.08$ & $0.07 \pm 0.08$ & -0.02 & $\mathbf{0 . 9 6}(0.90$ to 1.01$)$ \\
6CC NP & $25.26 \pm 0.11$ & $23.56 \pm 0.05$ & $1.7 \pm 0.12$ & $0.11 \pm 0.12$ & -0.03 & $\mathbf{0 . 9 3}(0.85$ to 1.01$)$ \\
\hline
\end{tabular}

CT - threshold cycle, SEM - standard error of the mean, * - endogenous control, ** - calibrator sample. $\Delta \mathrm{CT}=\mathrm{CT}$ (Target) - CT (Endogenous control). $\Delta \Delta \mathrm{CT}=\Delta \mathrm{CT}$ (Target $-\Delta \mathrm{CT}$ (Calibrator).

Table VI. RQ analysis of integrin $\beta 5$ gene expression in the luminal surface uterine epithelial cells of day 1 and day 6 of pregnant rats. A fold change of 1.5 or more represents a significant difference in gene expression $(\mathrm{p} \leq 0.05)$.

\begin{tabular}{|c|c|c|c|c|c|c|}
\hline Sample & Int 5 Ave $C_{\mathrm{T}}$ & ${ }^{*} \mathrm{RFG}$ Ave $\mathrm{C}_{\mathrm{T}}$ & $\Delta \mathrm{C}_{\mathrm{T}}$ & $\Delta \Delta \mathrm{C}_{\mathrm{T}}$ & $\log _{10}\left(2^{-\Delta \Delta C I}\right)$ & Fold change $2^{-\Delta \Delta C 1}$ \\
\hline$* * 1 \mathrm{U}$ & $27.8 \pm 0.02$ & $22.81 \pm 0.03$ & $4.99 \pm 0.04$ & $0 \pm 0.04$ & 0 & $\mathbf{1}(0.97$ to 1.03$)$ \\
\hline $1 \mathrm{~A}$ & $27.64 \pm 0.07$ & $22.75 \pm 0.04$ & $4.89 \pm 0.08$ & $-0.1 \pm 0.08$ & 0.03 & 1.07 (1.01 to 1.13$)$ \\
\hline $1 \mathrm{CC}$ & $27.39 \pm 0.05$ & $22.05 \pm 0.06$ & $5.34 \pm 0.08$ & $0.35 \pm 0.08$ & -0.10 & $\mathbf{0 . 7 9}(0.74$ to 0.83$)$ \\
\hline $6 \mathrm{U}$ IP & $26.88 \pm 0.06$ & $22.59 \pm 0.09$ & $4.29 \pm 0.11$ & $-0.7 \pm 0.11$ & 0.21 & $\mathbf{1 . 6 3}$ (1.51 to 1.75$)$ \\
\hline 6U NP & $26.96 \pm 0.02$ & $22.37 \pm 0.04$ & $4.59 \pm 0.04$ & $-0.4 \pm 0.04$ & 0.12 & 1.32 (1.29 to 1.35$)$ \\
\hline 6A IP & $26.30 \pm 0.06$ & $22.19 \pm 0.02$ & $4.11 \pm 0.06$ & $-0.88 \pm 0.06$ & 0.27 & $\mathbf{1 . 8 5}$ (1.77 to 1.92$)$ \\
\hline 6A NP & $27.41 \pm 0.02$ & $23.17 \pm 0.03$ & $4.24 \pm 0.04$ & $-0.75 \pm 0.04$ & 0.23 & 1.68 (1.64 to 1.73$)$ \\
\hline $6 \mathrm{CC}$ IP & $28.74 \pm 0.08$ & $23.52 \pm 0.05$ & $5.22 \pm 0.09$ & $0.23 \pm 0.09$ & -0.07 & $\mathbf{0 . 8 6}(0.8$ to 0.91$)$ \\
\hline $6 \mathrm{CC}$ NP & $29.83 \pm 0.01$ & $23.56 \pm 0.05$ & $6.27 \pm 0.05$ & $1.28 \pm 0.05$ & -0.38 & $\mathbf{0 . 4 2}(0.4$ to 0.43$)$ \\
\hline
\end{tabular}

$\mathrm{CT}$ - threshold cycle, SEM - standard error of the mean, * - endogenous control, ** - calibrator sample. $\Delta \mathrm{C}_{\mathrm{T}}=\mathrm{C}_{\mathrm{T}}($ Target $)-\mathrm{C}_{\mathrm{T}}($ Endogenous control). $\Delta \Delta \mathrm{C}_{\mathrm{T}}=\Delta \mathrm{C}_{\mathrm{T}}$ (Target $-\Delta \mathrm{C}_{\mathrm{T}}$ (Calibrator). 
epithelium at day 1 of pregnancy whereas at day 6, they disassemble from the basal focal adhesions and co-localize and significantly increase their expression apically $(\mathrm{p} \leq 0.0001)$. Additionally, vinculin is also expressed in the perinuclear region at day 1 and relocates apically at day 6 of pregnancy. Moreover, there is a significant difference in the protein expression levels of both vinculin and integrin b5 between untreated (control) and chlomiphene citrate (CC) treated rats $(\mathrm{p} \leq 0.0001)$, anastrozole and chlomiphene citrate $(\mathrm{CC})$ treated rats at day $6(\mathrm{p} \leq 0.0001)$ suggesting the interpretation that $\mathrm{CC}$ seems to decrease their expression. Although there is no significant difference in the expression levels between untreated and anastrozole treated rats at day 1 and day $6(\mathrm{p} \leq 0.05)$, the means for vinculin and integrin $\beta 5$ protein expression are higher in the anastrozole treated groups suggesting perhaps, that anastrozole seems to enhance their expression in order to assist in the implantation process of the embryo.

Moreover, vinculin and integrin $\beta 5$ gene expression in uterine luminal epithelial cells at day 1 of pregnancy agrees with the protein expression. Vinculin gene expression is fairly similar $(1.2$-fold increase $)(p \leq 0.05)$ in the anastrozole treated rats relative to the calibrator sample (day 1 untreated rats). This is also true for integrin $\beta 5$ gene expression (1.01-fold increase) $(\mathrm{p} \leq 0.05)$ suggesting the interpretation that anastrozole seems not to retard vinculin and integrin $\beta 5$ gene expression in the process of endometrial readiness for implantation. Vinculin and integrin b5 gene expression in uterine luminal epithelial cells, however, is down-regulated (0.77-fold decrease) and (0.79-fold decrease) respectively with chlomiphene citrate (CC) treatment at day 1 of pregnancy relative to the calibrator sample, which may suggest that CC perhaps decreases their expression. Interestingly, like the immunofluorescence experiments, at day 6 of pregnancy, vinculin and integrin $\beta 5$ gene expression are significantly up-regulated (more than 1.5-fold increase) $(\mathrm{p} \leq 0.0001)$ in uterine luminal epithelial cells in the implantation and nonimplantation sites in the anastrozole treated group relative to the calibrator sample. A significant increase in the integrin $\beta 5$ gene expression is also noted in uterine luminal epithelial cells of day 6 implantation sites in the untreated group (more than 1.5 -fold increase) $(\mathrm{p} \leq 0.0001)$ while it has remained similar (1.04-fold increase) $(\mathrm{p} \leq 0.05)$ in the nonimplantation sites relative to the calibrator sample suggesting the interpretation that anastrozole appears to enhance their expression to probably assist in blastocyst implantation. However, vinculin gene expression in uterine luminal epithelial cells is down-regulated with chlomiphene citrate $(\mathrm{CC})$ treatment at day 6 in implantation sites (0.96fold decrease) relative to the calibrator sample. This is also true for integrin $\beta 5$ gene expression (0.86-fold decrease), which may suggest that chlomiphene citrate (CC) may lag endometrial receptivity. In general, there is an increase in vinculin and integrin $\beta 5$ gene expression at day 6 of pregnancy in uterine luminal epithelial cells in untreated and anastrozole treated groups, as reflected in the immunofluorescence experiments, in order to perhaps assist in implantation.

Vinculin is one of the core and best characterized focal adhesion (FA) proteins (Humphries et al., 2007; Carisey et al., 2013). Tyrosine phosphorylation of vinculin modifies focal adhesion dynamics and cell tractions (Küpper et al., 2010). Vinculin regulates the recruitment and release of other core focal adhesion proteins in a force dependent manner and interacts with the talin-integrin complex and thus drives the recruitment and release of core FA components (Humphries et al.; Carisey et al.). Earlier studies demonstrated that lack of cytoskeletal connecting proteins like vinculin, talin and focal adhesion kinase (FAK) reduces the overall cellular binding strength (Carisey et al.). As mentioned earlier, focal adhesions disassemble from the base of uterine luminal epithelial cells at the time of implantation to facilitate their removal so that the implanting blastocyst can invade into the underlying endometrial decidual cells during early pregnancy in the rat (Kaneko et al., 2009). Kaneko et al. (2009) showed a major core FA protein talin distributional change between different hormone regimes. Talin is highly concentrated along the basal cell surface of uterine luminal epithelial cells in response to estrogen treatment which is observed at day 1 of pregnancy. However, this prominent staining of talin is absent in response to progesterone alone or progesterone in combination with estrogen, which is also observed at the time of implantation (Kaneko et al., 2009). This supports one of the important findings of the present study as noted in the immunofluorescence experiments in which FA proteins vinculin and integrin b5 disassemble from the base of the uterine epithelium at day 1 of pregnancy and co-localize and increase their expression apically at day 6 of pregnancy to facilitate the implantation process.

Of particular significance, the disassembly of vinculin and integrin $\beta 5$ from the basal focal adhesions and their apical expression increase at day 6 of pregnancy in the anastrozole treated rats means that anastrozole may favor implantation. Moreover, integrin aVb3 is required for endometrial receptivity (Zhang et al., 2011). Other studies demonstrated that human preimplantation embryos constitutively express integrin b3 and integrin $\beta 5$ subunit proteins (Bloor et al., 2002). Put together, this means that integrins play a role in the implantation process and could be regulated by agents that are known to alter cell behavior such as anastrozole and chlomiphene citrate (CC). 
On the other hand, the decrease in the apical vinculin and integrin $\beta 5$ expression with chlomiphene citrate (CC) treatment at day 6 in the current study may suggest the interpretation that $\mathrm{CC}$ might negatively affect the implantation process in this regard. This agrees with earlier studies that also observed a decrease in uterine integrin $\beta 3$ expression in chlomiphene citrate (CC) treated patients during the window of implantation, suggesting that chlomiphene citrate (CC) might affect the expression of uterine receptivity markers (Palomino et al., 2005). On the contrary, other studies noted that chlomiphene citrate (CC) does not affect the secretion of integrin $\alpha 3$, integrin $\mathrm{aV}$ and integrin b1 during the implantation window in patients with unexplained infertility (Lacin et al., 2001). All in all, chlomiphene citrate (CC) appears to negatively affect the implantation process by down-regulating the expression of key implantation markers such as vinculin and integrin $\beta 5$ and thus being associated with low pregnancy rates.

Additionally, other studies done on the effects of letrozole and chlomiphene citrate (CC) on the expression of integrin $\alpha_{\mathrm{v}} \beta_{3}$ during implantation in rats demonstrated that the expression of integrin $\alpha_{\mathrm{v}} \beta_{3}$ in the CC group is significantly lower than in the letrozole and saline groups (Bao et al., 2009) suggesting that $\mathrm{CC}$ suppresses uterine receptivity more than letrozole (Bao et al.). Similar observations are made by previous studies in which the expression of the molecular markers of endometrial receptivity, integrin $\alpha_{v} \beta_{3}$ and glycodelin, are decreased in endometrial biopsy specimens from women with PCOS when ovulation is induced with clomiphene citrate (Gonzalez et al., 2001; Jakubowicz et al., 2001). Interestingly, these observations agree with the results of the current study in which integrin $\beta 5$ expression in the uterine luminal epithelial cells of CC treated rats is significantly lower than anastrozole and untreated groups during implantation $(\mathrm{p} \leq 0.0001)$. However, in the present study, integrin $\beta 5$ disassembles from the basal focal adhesions and later get localized at the apical plasma membrane of the rat uterine luminal epithelial cells at the time of implantation as also noted by (Kaneko et al., 2011) in their studies with integrin $\beta 3$. Moreover, integrin $\beta 5, \beta 3$ and $\mathrm{aV}$ are apically distributed in uterine epithelial cells during implantation (Aplin \& Kimber, 2004) suggesting their crucial role in the implantation process. Similarly, Creus et al. (2003) have shown that the human endometrial maturity is characterized by integrin aVb3 expression and pinopod formation. Therefore, this clearly shows that integrins (including integrins $\beta 5$ ) are pivotal with regard to blastocyst-uterus interaction during early pregnancy. Viewed in its totality, anastrozole seems to enhance the focal adhesion protein vinculin and integrin $\beta 5$ expression at day 6 suggesting the interpretation that anastrozole is implantation friendly as also evidenced by its high implantation rates (Mwakikunga \& Hosie).

\section{CONCLUSIONS}

The immunofluorescence and gene expression results for the uterine receptivity markers FA proteins vinculin and integrins $\beta 5$ appear to demonstrate that anastrozole is implantation friendly. It is also important to note that anastrozole is a competitive inhibitor of aromatase in the conversion of androgens to estrogens $\left(\mathrm{E}_{2}\right)$; therefore, the $15 \mathrm{mg} / \mathrm{kg}$ anastrozole dose, which is effective in causing ovulation, may allow just enough of the intermediates and $\mathrm{E}_{2}$ to be present with regard to the hormone profiles for ovulation and successful implantation of the embryo. Essentially, it may appear that there is blocking of E2 and increasing of androgens in anastrozole treated rats compared to controls. Progesterone $(\mathrm{P})$ is probably also high as $\mathrm{E}_{2}$ is low. In chlomiphene citrate (CC) treated rats, estrogen receptors might be blocked, which increases $\mathrm{E}_{2}$. The effect of anastrozole in the level of $\mathrm{E}_{2}$ and $\mathrm{P}$ may change the E2/P ratio at day 6 of pregnancy, suggesting its effect on endometrial maturation and therefore improving receptivity. If this is true, the advantage of anastrozole therapy over chlomiphene citrate (CC) may be the lower $\mathrm{E}_{2} / \mathrm{P}$ ratio and increased levels of FSH and LH. Therefore, measuring parameters such as the intermediates, estrogens and androgens in future studies may also be of use in determining hormonal profiles for implantation. Anastrozole may be a suitable replacement or alternative drug used for hyperovulation or just to promote fertility in patients, particularly those suffering from polycystic ovary syndrome and those that are unresponsive to chlomiphene citrate $(\mathrm{CC})$.

\section{ACKNOWLEDGMENTS}

We thank the staff of the Central Animal Unit and the School of Anatomical Sciences of the University of the Witwatersrand, South Africa and the staff and management of Newcastle University, NuMed Malaysia Campus for their support.

MWAKIKUNGA, A.; ADEFOLAJU, G. A.; SCHEPARTZ, L. \& HOSIE, M. J. Proteínas de adhesión focales, vinculina e integrina $\beta 5$, durante el embarazo temprano en células epiteliales uterinas de rata: Anastrozol favorece su distribución normal. Int. J. Morphol., 36(1):345-357, 2017.

RESUMEN: Es necesario un superovulador alternativo para reemplazar el citrato de clomifeno, debido a que está asociado con bajas tasas de preñez. El anastrozol es un superovulador eficaz, sin embargo es poca su investigación. Con el fin de deter- 
minar la efectividad del anastrozol como superovulador y compararlo con citrato de clomifeno en situaciones similares, se determinaron los efectos de estos fármacos sobre la expresión de las proteínas de adhesión focal, vinculina e integrina $\beta 5$, en marcadores de receptividad uterina en días 1 y 6 , en las células epiteliales uterinas de ratas Wistar preñadas. Los resultados muestran que la vinculina y la integrina $\beta 5$ se co-localizan en la base del epitelio uterino al día 1 de la gravidez mientras que al día 6 se desmontan de las adherencias focales basales, co-localizan y aumentan significativamente su expresión apicalmente $(\mathrm{p} \leq 0.0001)$. Además, existe una diferencia significativa en los niveles de expresión de proteína de vinculina e integrina $\beta 5$ en células epiteliales luminales uterinas entre ratas no tratadas (control) y tratadas con citrato de clomifeno $(\mathrm{p} \leq 0.0001)$, ratas tratadas con anastrozol y citrato de clomifeno al día $6(\mathrm{p} \leq 0,0001)$ sugiriendo la interpretación de que el anastrozol parece mejorar su expresión con el fin de ayudar en el proceso de implantación del blastocisto. Los experimentos de inmunofluorescencia coinciden con los resultados de la expresión de los genes vinculina e integrina $\beta 5$ en los cuales al día 6 de la preñez, la vinculina y la integrina $\beta 5$ están significativamente reguladas en células epiteliales luminales uterinas en el grupo tratado con anastrozol con respecto a la muestra del calibrador $(p<0,0001)$. Estos hallazgos sugieren que el anastrozol es favorable para la implantación.

PALABRAS CLAVE: Implantación; Útero; Embarazo prematuro; Vinculina; Integrina b5; Proteínas de adhesión focal.

\section{REFERENCES}

Al-Bader, M. D. \& Al-Sarraf, H. A. Housekeeping gene expression during fetal brain development in the rat-validation by semi-quantitative RT-PCR. Brain Res. Dev. Brain Res., 156(1):38-45, 2005.

Al-Omari, W. R.; Sulaiman, W. R. \& Al-Hadithi, N. Comparison of two aromatase inhibitors in women with clomiphene-resistant polycystic ovary syndrome. Int. J. Gynaecol. Obstet., 85(3):289-91, 2004.

Aplin, J. D. \& Kimber, S. J. Trophoblast-uterine interactions at implantation. Reprod. Biol. Endocrinol., 2:48, 2004.

Bao, S. H.; Sheng, S. L.; Peng, Y. F. \& Lin, Q. D. Effects of letrozole and clomiphene citrate on the expression of HOXA10 and integrin alpha V beta 3 in uterine epithelium of rats. Fertil. Steril., 91(1):244-8, 2009.

Bloor, D. J.; Metcalfe, A. D.; Rutherford, A.; Brison, D. R. \& Kimber, S. J. Expression of cell adhesion molecules during human preimplantation embryo development. Mol. Hum. Reprod., 8(3):237-45, 2002.

Bruna-Catalán, I.; Menabrito, M. \& Spanish Collaborative Group. Ovulation induction with minimal dose of follitropin alfa: a case series study. Reprod. Biol. Endocrinol., 9:142, 2011.

Carisey, A.; Tsang, R.; Greiner, A. M.; Nijenhuis, N.; Heath, N.; Nazgiewicz, A.; Kemkemer, R.; Derby, B.; Spatz, J. \& Ballestrem, C. Vinculin regulates the recruitment and release of core focal adhesion proteins in a force-dependent manner. Curr. Biol., 23(4):271-81, 2013.

Casper, R. F. \& Mitwally, M. F. A historical perspective of aromatase inhibitors for ovulation induction. Fertil. Steril., 98(6):1352-5, 2012.

Casper, R. F. \& Mitwally, M. F. Use of the aromatase inhibitor letrozole for ovulation induction in women with polycystic ovarian syndrome. Clin. Obstet. Gynecol., 54(4):685-95, 2011.

Creus, M.; Ordi, J.; Fábregues, F.; Casamitjana, R.; Carmona, F.; Cardesa, A.; Vanrell, J. A. \& Balasch, J. The effect of different hormone therapies on integrin expression and pinopode formation in the human endometrium: a controlled study. Hum. Reprod., 18(4):683-93, 2003.

Enders, A. C.; Schlafke, S. \& Hendrickx, A. G. Differentiation of the embryonic disc, amnion, and yolk sac in the rhesus monkey. Am. J. Anat., 177(2):161-85, 1986.

Englund, P.; Lindroos, E.; Nennesmo, I.; Klareskog, L. \& Lundberg, I. E. Skeletal muscle fibers express major histocompatibility complex class II antigens independently of inflammatory infiltrates in inflammatory myopathies. Am. J. Pathol., 159(4):1263-73, 2001.

Fabry, B.; Klemm, A. H.; Kienle, S.; Schäffer, T. E. \& Goldmann, W. H. Focal adhesion kinase stabilizes the cytoskeleton. Biophys. J., 101(9):2131-8, 2011.

Fatum, M.; Gyo, Y.; Diana, P.; Laufer, N. \& Simon, A. Is estradiol mandatory for an adequate follicular and embryo development? A mouse model using aromatase inhibitor (anastrozole). J. Assist. Reprod. Genet., 23(11-12):407-12, 2006.

Franik, S.; Kremer, J. A.; Nelen, W. L. \& Farquhar, C. Aromatase inhibitors for subfertile women with polycystic ovary syndrome. Cochrane Database Syst. Rev., (2):CD010287, 2014.

Gilmore, A. P. \& Burridge, K. Regulation of vinculin binding to talin and actin by phosphatidyl-inositol-4-5-bisphosphate. Nature, 381(6582):531-5, 1996.

Gonzalez, R. R.; Palomino, A.; Vantman, D.; Gabler, F. \& Devoto, L. Abnormal pattern of integrin expression at the implantation window in endometrium from fertile women treated with clomiphene citrate and users of intrauterine device. Early Pregnancy, 5(2):132-43, 2001.

Grewal, S.; Carver, J.; Ridley, A. J. \& Mardon, H. J. Human endometrial stromal cell rho GTPases have opposing roles in regulating focal adhesion turnover and embryo invasion in vitro. Biol. Reprod., 83(1):75-82, 2010.

Hirata, H.; Sokabe, M. \& Lim, C. T. Molecular mechanisms underlying the force-dependent regulation of actin-to-ECM linkage at the focal adhesions. Prog. Mol. Biol. Transl. Sci., 126:135-54, 2014.

Hong, E. J.; Park, S. H.; Choi, K. C.; Leung, P. C. \& Jeung, E. B. Identification of estrogen-regulated genes by microarray analysis of the uterus of immature rats exposed to endocrine disrupting chemicals. Reprod. Biol. Endocrinol., 4:49, 2006.

Hosie, M.; Adamson, M. \& Penny, C. Actin binding protein expression is altered in uterine luminal epithelium by clomiphene citrate, a synthetic estrogen receptor modulator. Theriogenology, 69(6):70013, 2008.

Hosie, M.; Terry, V. \& Murphy, C. Expression of glucosamine trisaccharides on the rat uterine surface is altered by clomiphene citrate. III. Relationship with implantation regimes and pregnancy. Acta Histochem., 105(4):329-38, 2003.

Humphries, J. D.; Wang, P.; Streuli, C.; Geiger, B.; Humphries, M. J. \& Ballestrem, C. Vinculin controls focal adhesion formation by direct interactions with talin and actin. J. Cell Biol., 179(5):1043-57, 2007.

Jakubowicz, D. J.; Seppälä, M.; Jakubowicz, S.; Rodriguez-Armas, O.; Rivas-Santiago, A.; Koistinen, H.; Koistinen, R. \& Nestler, J. E. Insulin reduction with metformin increases luteal phase serum glycodelin and insulin-like growth factor-binding protein 1 concentrations and enhances uterine vascularity and blood flow in the polycystic ovary syndrome. J. Clin. Endocrinol. Metab., 86(3):1126-33, 2001.

Jaramillo, L. M.; Balcazar, I. B. \& Duran, C. Using vaginal wall impedance to determine estrous cycle phase in Lewis rats. Lab. Anim. (N. Y.), 41(5):122-8, 2012.

Kamath, M. S. \& George, K. Letrozole or clomiphene citrate as first line for anovulatory infertility: A debate. Reprod. Biol. Endocrinol., 9:86, 2011.

Kaneko, Y.; Lecce, L. \& Murphy, C. R. Ovarian hormones regulate expression of the focal adhesion proteins, talin and paxillin, in rat uterine luminal but not glandular epithelial cells. Histochem. Cell. Biol., 132(6):613-22, 2009.

Kaneko, Y.; Lecce, L.; Day, M. L. \& Murphy, C. R. b(1) and b(3) integrins disassemble from basal focal adhesions and $b(3)$ integrin is later 
localised to the apical plasma membrane of rat uterine luminal epithelial cells at the time of implantation. Reprod. Fertil. Dev., 23(3):481-95, 2011.

Kaneko, Y.; Lindsay, L. A. \& Murphy, C. R. Focal adhesions disassemble during early pregnancy in rat uterine epithelial cells. Reprod. Fertil. Dev., 20(8):892-9, 2008.

Karaer, O.; Vatansever, H. S.; Oruç, S.; Ozbilgin, K.; Cilaker, S. \& Koyuncu, M. F. The aromatase inhibitor anastrozole is associated with favorable embryo development and implantation markers in mice ovarian stimulation cycles. Fertil. Steril., 83(6):1797-806, 2005.

Kilic-Okman, T.; Kucuk, M. \& Altaner, S. Comparison of the effects of letrozole and clomiphene citrate on ovarian follicles, endometrium, and hormone levels in the rat. Fertil. Steril., 80(6):1330-2, 2003.

Küpper, K.; Lang, N.; Möhl, C.; Kirchgessner, N.; Born, S.; Goldmann, W. H.; Merkel, R. \& Hoffmann B. Tyrosine phosphorylation of vinculin at position 1065 modifies focal adhesion dynamics and cell tractions. Biochem. Biophys. Res. Commun., 399(4):560-4, 2010.

Lacin, S.; Vatansever, S.; Kuscu, N. K.; Koyuncu, F.; Ozbilgin, K. \& Ceylan, E. Clomiphene citrate does not affect the secretion of alpha3, alphaV and beta1 integrin molecules during the implantation window in patients with unexplained infertility. Hum. Reprod., 16(11):23059, 2001

Lee, V. C. \& Ledger, W. Aromatase inhibitors for ovulation induction and ovarian stimulation. Clin. Endocrinol. (Oxf.), 74(5):537-46, 2011.

Lele, T. P.; Thodeti, C. K.; Pendse, J. \& Ingber, D. E. Investigating complexity of protein-protein interactions in focal adhesions. Biochem. Biophys. Res. Commun., 369(3):929-34, 2008.

Li, D.; Sakuma, R.; Vakili, N. A.; Mo, R.; Puviindran, V.; Deimling, S.; Zhang, X. ; Hopyan, S. \& Hui, C. C. Formation of proximal and anterior limb skeleton requires early function of Irx 3 and Irx 5 and is negatively regulated by Shh signaling. Dev. Cell., 29(2):233-40, 2014.

Mohan, K. H.; Pai, S.; Rao, R.; Sripathi, H. \& Prabhu, S. Techniques of immunofluorescence and their significance. Indian J. Dermatol. Venereol. Leprol., 74(4):415-9, 2008.

Murphy, C. R. Uterine receptivity and the plasma membrane transformation. Cell Res., 14(4):259-67, 2004.

Mwakikunga, A. \& Hosie, M. J. Anastrozole is a dose-specific superovulator and favors implantation in rats: a prospective study. Cell Tissue Res., 364(1):209-17, 2016.

Mwakikunga, A. M.; Clubine, A. L. \& Wiens, D. J. Homocysteine and cardiac neural crest cell cytoskeletal proteins in the chick embryo. Int. J. Biol., 3(2):43-56, 2011.

Pakrasi, P. L. \& Tiwari, A. Evidence of increased endometrial vascular permeability at the time of implantation in the short-nosed fruit bat, Cyanopterus sphinx. Anim. Reprod. Sci., 101(1-2):179-85, 2007.

Palomino, W. A.; Fuentes, A.; González, R. R.; Gabler, F.; Boric, M. A.; Vega, M. \& Devoto, L. Differential expression of endometrial integrins and progesterone receptor during the window of implantation in normo-ovulatory women treated with clomiphene citrate. Fertil. Steril., 83(3):587-93, 2005.

Paria, B. C.; Song, H. \& Dey, S. K. Implantation: molecular basis of embryo-uterine dialogue. Int. J. Dev. Biol., 45(3):597-605, 2001.

Psychoyos, A. Uterine receptivity for nidation. Ann. N. Y. Acad. Sci., 476:36-42, 1986.

Rajamohamedsait, H. B. \& Sigurdsson, E. M. Histological staining of amyloid and pre-amyloid peptides and proteins in mouse tissue. Methods Mol. Biol., 849:411-24, 2012.

Schmittgen, T. D. \& Livak, K. J. Analyzing real-time PCR data by the comparative C(T) method. Nat. Protoc., 3(6):1101-8, 2008.

Singletary, S. J.; Kirsch, A. J.; Watson, J.; Karim, B. O.; Huso, D. L.; Hurn, P. D. \& Murphy, S. J. Lack of correlation of vaginal impedance measurements with hormone levels in the rat. Contemp. Top. Lab. Anim. Sci., 44(6):37-42, 2005.

Tredway, D. R. \& Schertz, J. C. Anastrozole versus clomiphene citrate: which is better for ovulation induction? Fertil. Steril., 95(5):1549$51,2011$.
Zhang, D.; Wei, J.; Wang, J.; Liu, S.; Wang, X. \& Yan, Q. Difucosylated oligosaccharide Lewis $\mathrm{Y}$ is contained within integrin avb3 on RL952 cells and required for endometrial receptivity. Fertil. Steril., 95(4):1446-51.e1, 2011.

\section{Corresponding author: \\ Gbenga A Adefolaju}

Department of Pre-clinical Sciences

School of Health Care Sciences

University of Limpopo

Private Bag x1106

Sovenga 0727

SOUTH AFRICA

\section{E-mail: gbenga.adefolaju@ul.ac.za anton.ul2016@gmail.com}

Received: 08-02-2017

Accepted: 03-05-2017 